\title{
PENGARUH BUDAYA ORGANISASI DAN STATUS SOSIAL EKONOMI TERHADAP KOMPETENSI PROFESIONAL GURU DI SMA NEGERI 13 SURABAYA
}

\author{
Purwo Cahyono*
}

\begin{abstract}
This study aimed to determine the influence of organizational culture and socioeconomic status on the teachers' professional competency. This study was an explanatory research using a quantitative approach. The population covers 59 teachers at the 13th State Senior High School of Surabaya. Sample was 51 teachers with two different classes which determined using proportionate stratified random sampling technique, with Slovin formula. The Data were collected using questionnaires and documentations. The Analyzed of the data were quantitatively using simple and multiple linear regression. The hypothesis was tested using the t test and $F$ test technique. Based on the research results, it was concluded that: (1) There is a partial influence of organizational culture on teachers' professional competency, (2) There is a partial influence of socio - economic status on teachers 'professional competency, and (3) There are simultaneous influences of organizational culture and socioeconomic status on the teachers' professional competency.
\end{abstract}

Keywords: organizational culture, socioeconomic status, teachers' professional competency.

\section{PENDAHULUAN}

$\mathrm{K}^{\mathrm{s}}$ eberhasilan sekolah sebagai lembaga pendidikan yang bertujuan menghasilkan sumber daya manusia (SDM) berkualitas, tidak akan lepas dari peran sebuah organisasi yang ada dan dibangun dalam sekolah tersebut. Seperti halnya dengan organisasi yang lain, organisasi sekolah juga merupakan organisasi dengan sistem terbuka yang selalu bergantung pada lingkungan dimana organisasi itu berada.

Guru merupakan salah satu penentu keberhasilan pencapaian tujuan sekolah. Melalui guru-guru yang kompeten dan profesional, pembelajaran berkualitas dapat dilaksanakan. Terdapat empat macam kompetensi yang harus dikuasai guru. Menurut Undang-undang Republik Indonesia Nomor 14 tahun 2005 tentang Guru dan Dosen, disebutkan bahwa kompetensi guru sebagaimana dimaksud dalam Pasal 8 meliputi kompetensi pedagogik, kompetensi kepribadian, kompetensi sosial, dan kompetensi profesional yang diperoleh melalui pendidikan profesi.

Kompetensi profesional guru merupakan seperangkat penguasaan kemampuan yang luas dan mendalam berkaitan dengan profesinya sebagai guru. Direktorat Ketenagaan Dirjen Dikti dan Direktorat Profesi Pendidik Ditjen PMPTK Depdiknas (dalam Kunandar, 2007: 77) menyatakan bahwa kompetensi profesional merupakan penguasaan materi pembelajaran secara luas dan mendalam, yang mencakup penguasaan materi kurikulum mata pelajaran di sekolah dan substansi keilmuan yang menaungi materinya, serta pen-

*) Guru SMA Negeri 13 Surabaya 
guasaan terhadap struktur dan metodologi keilmuannya.

Guru disebut memiliki kompetensi profesional apabila telah memenuhi persyaratan sesuai peraturan yang berlaku. Permendiknas Nomor 16 tahun 2007 tentang standar kualifikasi akademik dan kompetensi guru telah mengatur persyaratan kompetensi profesional yaitu: menguasai materi, struktur, konsep dan pola pikir keilmuan yang mendukung mata pelajaran yang diampu, menguasai standar kompetensi dan kompetensi dasar mata pelajaran/bidang pengembangan yang diampu, mengembangkan materi pembelajaran yang diampu secara kreatif, mengembangkan keprofesionalan secara berkelanjutan dengan melakukan tindakan reflektif, dan memanfaatkan teknologi informasi dan komunikasi untuk mengembangkan diri. Berdasarkan observasi awal di SMA Negeri 13 Surabaya diketahui bahwa semua guru PNS telah bersertifikat pendidik, namun masih sebagian kecil guru yang mampu memanfaatkan teknologi informasi dan komunikasi untuk pembelajaran.

Komitmen guru dalam meningkatkan kompetensi profesionalnya tidak akan terlepas dari kuat atau lemahnya budaya organisasi yang ada di sekolah. Budaya organisasi merupakan pola asumsi dasar, nilai-nilai, keyakinan, perilaku yang dipegang teguh, dianut serta dikembangkan secara terus menerus dalam berbagai tantangan dan permasalahan yang muncul di dalam organisasi sekolah yang melibatkan kepala sekolah, guru, karyawan sekolah, siswa dan orang tua siswa. McShane (2008: 460) mendefinisikan budaya organisasi sebagai "Organizational culture consists of the values and assumptions shared within an organization. It defines what is important and unimportant in the company and consequently directs everyone in the organization toward the "right way" of doing things."

Melalui dua komponen budaya organisasi yang disampaikan Robbins (2007: 721) yaitu inisiatif individual dan toleransi tindakan berisiko dengan indikator kadar kebebasan, tanggung jawab atas inisiatif, peluang/kesempatan berinisiatif, dorongan untuk agresif, dorongan untuk inovatif, dan berani menanggung risiko membentuk guru untuk berperilaku menurut teori Y daripada teori X.

McGregor (dalam Robbins, 2002: 57) menyebutkan bahwa "seseorang itu pada dasarnya bersifat negatif, diberi nama teori $\mathrm{X}$, dan yang lainnya pada dasarnya bersifat positif, diberi nama teori Y.” Kuatnya perilaku berdasarkan teori Y yang muncul dalam budaya organisasi di sekolah mengarahkan mental positif guru untuk meningkatkan kompetensi profesionalnya.

Budaya organisasi yang berlaku di sekolah memberi semangat kepada guru untuk membawa kesuksesan sekolah mencapai tujuan-tujuannya. McShane (2008: 466) menyebutkan bahwa "a strong corporate culture potentially increases a company's success." Dengan demikian budaya organisasi yang kuat akan mampu menyelesaikan permasalahan kompetensi profesional guru dan menjamin peningkatan kesuksesan organisasi sekolah untuk mencapai tujuan-tujuan yang telah direncanakan.

Status sosial ekonomi merupakan faktor lain yang melekat pada diri guru. Status sosial ekonomi merupakan kedudukan seseorang di dalam lingkungan kelompok masyarakatnya berdasarkan pengakuan sosial dan kemampuan memenuhi kebutuhannya. Schiffman (2008: 330) menyebutkan "status paling sering ditentukan dari sudut satu variabel demografis atau lebih cocok sosio ekonomi: penghasilan keluarga, status pekerjaan, dan pencapaian pendidikan." Latar belakang pendidikan berhubungan erat dengan status pekerjaannya dan berkontribusi pada tinggi/rendahnya penghasilan yang akan diperoleh. 
Latar belakang pendidikan menjadi hal yang penting bagi seorang guru. Latar belakang pendidikan yang dipersyaratkan sebagai guru sesuai yang diamanatkan dalam Undang-undang Republik Indonesia Nomor 14 Tahun 2005 tentang Guru dan Dosen, pada pasal 9, bahwa "Kualifikasi akademik sebagaimana dimaksud dalam pasal 8 diperoleh melalui pendidikan tinggi program sarjana atau program diploma empat." Kondisi kualifikasi akademik guru di SMA Negeri 13 Surabaya diketahui bahwa masih terdapat guru berkualifikasi akademik D-III, seperti dapat dilihat dalam tabel di bawah ini.

Tabel 1. Kualifikasi Akademik Guru SMA Negeri 13 Surabaya

\begin{tabular}{|l|l|l|l|l|l|l|l|}
\hline \multirow{3}{*}{ NO } & \multirow{2}{*}{$\begin{array}{c}\text { KUALIFI- } \\
\text { KASI }\end{array}$} & \multicolumn{4}{|c|}{ STATUS } & \multirow{3}{*}{$\begin{array}{c}\text { NON } \\
\text { JML }\end{array}$} & \multirow{2}{*}{$\begin{array}{c}\text { PERSEN } \\
\text { TASE }\end{array}$} \\
\cline { 3 - 5 } & AKADEMIK & GOL. III & GOL. IV & JML & PNS & & \\
\hline 1 & D-III & 0 & 1 & 1 & 0 & 1 & $1,5 \%$ \\
\hline 2 & S-1 & 15 & 29 & 44 & 9 & 53 & $77,9 \%$ \\
\hline 3 & S-2 & 4 & 10 & 14 & 0 & 14 & $20,6 \%$ \\
\hline \multicolumn{2}{|l|}{ JUMLAH } & 19 & 40 & 59 & 9 & 68 & $100 \%$ \\
\hline
\end{tabular}

Sumber: Ketatausahaan SMA Negeri 13 Surabaya

Selain latar belakang pendidikan dan penghasilan, faktor fasilitas rumah yang dimiliki dan posisi sosial guru di dalam lingkungannya juga merupakan ukuran status sosial ekonomi. Schiffman (2008: 338) menyebutkan bahwa masih ada variabel lain yang bisa menjadi ukuran status sosial ekonomi seseorang yaitu: "kualitas lingkungan dan nilai tempat kediaman, dan barang-barang (perabot) yang dimiliki di dalam rumahnya".

Tidak hanya itu, guru dengan status sosial ekonomi yang baik akan mampu memenuhi kebutuhan dasar bagi keluarganya dan terpenuhinya fasilitas belajar yang mendukung pekerjaannya. Seperti ditulis oleh Albatch (dalam Dewi, 2010: 66) bahwa "guru yang memiliki penghasilan tinggi tidak hanya memungkinkan tercukupinya pemenuhan kebutuhan dasar keluarga, tetapi juga dapat memungkinkan tersedianya fasilitas belajar yang memadai di rumah untuk pengembangan kemampuan diri dan anak-anaknya”.

Penghargaan berkaitan dengan status sosial ekonomi dari lingkungan di mana guru berada, menjadikan mereka berupaya untuk selalu meningkatkan kompetensinya. Status sosial ekonomi menjadi penumbuh harapan bagi guru untuk lebih bersemangat dalam melaksanakan profesinya. Sebagaimana teori harapan (expectancy theory) yang disampaikan oleh Victor Vroom (dalam Karsono, 2005) yang berargumen bahwa "kuatnya kecenderungan untuk bertindak dalam suatu cara tertentu tergantung pada kekuatan suatu pengharapan bahwa tindakan itu akan diikuti oleh suatu keluaran tertentu dan pada daya tarik dari keluaran tersebut bagi individu itu."

Melalui kajian empirik dari beberapa penelitian terdahulu, terdapat beberapa faktor yang dapat mempengaruhi kompetensi profesional guru, di antaranya budaya organisasi dan status sosial ekonomi. Kedua faktor ini menjadi penting untuk diteliti kembali karena dalam penelitian terdahulu terbukti keduanya secara signifikan berpengaruh terhadap kompetensi profesional guru. Dengan karakteristik budaya organisasi melalui komponen inisiatif individual dan toleransi tindakan berisiko dan status sosial ekonomi guru di SMA Negeri 13 Surabaya, menjadi hal yang menarik untuk dilakukan penelitian guna menjaw- 
ab permasalahan tentang adakah pengaruh budaya organisasi dan status sosial ekonomi terhadap kompetensi profesional guru di SMA Negeri 13 Surabaya.

Berdasarkan uraian tentang pengaruh budaya organisasi dan status sosial ekonomi terhadap kompetensi profesional guru, maka disusun hipotesis kerja sebagai berikut:

1. Diduga ada pengaruh signifikan budaya organisasi terhadap kompetensi profesional guru di SMA Negeri 13 Surabaya.

2. Diduga ada pengaruh signifikan status sosial ekonomi terhadap kompetensi profesional guru di SMA Negeri 13 Surabaya.

3. Diduga ada pengaruh signifikan budaya organisasi dan status sosial ekonomi secara bersama-sama terhadap kompetensi profesional guru di SMA Negeri 13 Surabaya.

\section{METODE PENELITIAN}

Pendekatan dalam penelitian ini adalah pendekatan kuantitatif. Penelitian ini dirancang dengan menggunakan penelitian eksplanatori. Variabel yang digunakan pada penelitian ini adalah budaya organisasi (X1), status sosial ekonomi (X2), dan kompetensi profesional guru $(\mathrm{Y})$.

Tabel 2. Indikator Variabel Penelitian

\begin{tabular}{|l|l|l|l|}
\hline No & Variabel & Indikator & Sumber \\
\hline 1. & $\begin{array}{l}\text { Budaya Or- } \\
\text { ganisasi }\end{array}$ & $\begin{array}{l}\text { 1) Kadar kebebasan, 2) Tanggung jawab atas } \\
\text { inisiatif, 3) Peluang/kesempatan berinisiatif, } \\
\text { 4) Dorongan untuk agresif, 5) Dorongan } \\
\text { untuk inovatif, dan 6) Berani menanggung } \\
\text { resiko. }\end{array}$ & Robbins (2007: 721) \\
\hline 2. & $\begin{array}{l}\text { Status Sosial } \\
\text { Ekonomi }\end{array}$ & $\begin{array}{l}\text { 1) Latar belakang pendidikan, 2) Penghasi- } \\
\text { lan/pendapatan, 3) Kebutuhan dasar ke- } \\
\text { luarga, 4) Fasilitas rumah yang dimiliki, 5) } \\
\text { Fasilitas belajar yang mendukung pekerjaan- } \\
\text { nya, dan 6) Posisi sosial guru di dalam ling- } \\
\text { kungannya, baik lingkungan tempat tinggal } \\
\text { maupun di lingkungan tempat bekerja. }\end{array}$ & $\begin{array}{l}\text { Schiffman (2008: } \\
\text { (2006: 433), Secada } \\
\text { (dalam Dewi, 2010: } \\
\text { 62), Albach (dalam } \\
\text { Dewi, 2010: 66), } \\
\text { Sarimaya } \\
\text { (2008: }\end{array}$ \\
\hline 3. & $\begin{array}{l}\text { Kompetensi). } \\
\text { Profesional } \\
\text { Guru }\end{array}$ & $\begin{array}{l}\text { 1) Menguasai materi, struktur, konsep, dan } \\
\text { pola pikir keilmuan yang mendukung mata } \\
\text { pelajaran yang diampu, 2) Menguasai stan- } \\
\text { dar kompetensi dan kompetensi dasar mata } \\
\text { pelajaran yang diampu, 3) Mengembangkan } \\
\text { materi pembelajaran yang diampu secara } \\
\text { kreatif, 4) Mengembangkan keprofesiona- } \\
\text { lan secara berkelanjutan dengan melaku- } \\
\text { kan tindakan reflektif, 5) Memanfaatkan } \\
\text { teknologi informasi dan komunikasi untuk } \\
\text { mengembangkan diri. }\end{array}$ & $\begin{array}{l}\text { Lampiran Permen- } \\
\text { diknas Nomor 16 ta- } \\
\text { hun 2007. }\end{array}$ \\
\hline
\end{tabular}


Populasi dalam penelitian ini adalah guru-guru SMA Negeri 13 Surabaya yaitu sebanyak 59 orang. Seluruh anggota populasi dalam penelitian ini tidak digunakan sebagai sampel (sampling jenuh), seperti ditulis oleh Sugiyono (2001: 61) bahwa "sampling jenuh adalah teknik penentuan sampel bila semua anggota populasi digunakan sebagai sampel. Hal ini sering dilakukan bila jumlah populasi relatif kecil, kurang dari 30 orang". Maka sampel penelitian ditetapkan dengan teknik proportionate stratified random sampling menggunakan rumus Slovin sebanyak 51 orang. Pengumpulan data penelitian dilakukan dengan menyebarkan kuesioner dan mengumpulkan data dokumentasi dari ketatausahaan SMA Negeri 13 Surabaya. Kuesioner disusun berdasarkan variabel penelitian dan indikator penelitian dengan skala pengukuran instrumen menggunakan skala likert. Indikator yang digunakan untuk mengukur setiap variabel penelitian disarikan dalam tabel 2 .

Teknik analisis menggunakan analisis uji t dan uji F. Uji t digunakan untuk menguji signifikansi pengaruh budaya organisasi terhadap kompetensi profesional guru dan pengaruh status sosial ekonomi terhadap kompetensi profesional guru. Sedangkan uji F digunakan untuk menguji signifikansi pengaruh variabel budaya organisasi dan status sosial ekonomi terhadap kompetensi profesional guru.

\section{HASIL PENELITIAN DAN PEMBAHASAN}

\section{Hasil Penelitian}

Uji validitas dan reliabilitas atas instrumen penelitian menghasilkan bahwa seluruh pernyataan dalam instrumen penelitian dinyatakan valid dan reliabel. Kondisi jawaban responden atas instrumen penelitian pada masing-masing variabel penelitian disarikan sebagai berikut:

\section{Budaya organisasi}

Berdasarkan jawaban responden, kondisi budaya organisasi di SMA Negeri 13 Surabaya secara keseluruhan tergolong dalam kategori sangat tinggi. Skor rata-rata atas indikator budaya organisasi yang tertinggi adalah tanggung jawab atas inisiatif dan yang terendah adalah peluang berinisiatif. Secara lengkap perolehan skor rata-rata indikator budaya organisasi sebagai berikut: kadar kebebasan (dalam kategori sangat tinggi) sebanyak $17,33 \%$, tanggung jawab atas inisiatif (dalam kategori sangat tinggi) sebanyak $17,76 \%$, peluang berinisiatif (dalam kategori tinggi) sebanyak $14,29 \%$, dorongan untuk agresif (dalam kategori sangat tinggi) sebanyak 16,73\%, dorongan untuk inovatif (dalam kategori sangat tinggi) sebanyak 16,85\%, dan berani menanggung risiko (dalam kategori sangat tinggi) sebanyak $17,25 \%$.

\section{Status sosial ekonomi}

Berdasarkan jawaban responden, kondisi status sosial ekonomi guru di SMA Negeri 13 Surabaya secara keseluruhan tergolong dalam kategori baik. Skor rata-rata atas indikator status sosial ekonomi yang tertinggi adalah kebutuhan dasar keluarga dan yang terendah adalah fasilitas belajar yang mendukung pekerjaan. Secara lengkap perolehan skor rata-rata indikator status sosial ekonomi sebagai berikut: kebutuhan dasar keluarga (dalam kategori sangat baik) sebanyak 26,51\%, fasilitas rumah yang dimiliki (dalam kategori baik) sebanyak $25,94 \%$, fasilitas belajar yang mendukung pekerjaan (dalam kategori baik) sebanyak $22,80 \%$, dan posisi sosial di dalam lingkungannya (dalam kategori baik) 
sebanyak $24,75 \%$.

Lebih lanjut latar belakang pendidikan terakhir yang pernah dinikmati guru tertinggi adalah S-1/Diploma IV yaitu sebanyak 76,4\%. Guru dengan latar belakang pendidikan S-2 sebanyak 21,6\%, dan hanya 2\% yang berlatar belakang pendidikan Sarjana Muda/DIII.

Guru di SMA Negeri 13 Surabaya paling sering mengikuti kegiatan peningkatan pengetahuan yang berkaitan dengan pekerjaan (pertemuan MGMP kota, workshop, seminar, lokakarya, dll) rata-rata dalam 1 bulan sekali yaitu 84,3\%. Sebanyak 7,8\% guru mengikuti kegiatan ini dalam sebulan sebanyak lebih dari 3 kali. Guru yang mengikuti sebulan 2 kali sebanyak 5,9\% dan yang mengikuti kegiatan tersebut sebulan 3 kali sebanyak $2 \%$.

Menurut gaji yang diperoleh setiap bulan, paling banyak mendapatkan gaji yang tergolong tinggi yaitu antara $\mathrm{Rp} 3.988 .201,00$ - Rp 4.699.500,00 sebanya 49\% guru. Sebanyak 35,3\% guru mendapatkan gaji antara Rp 2.565.600,00 - Rp 3.276.900,00 yang tergolong rendah. Sedangkan sisanya sebanyak $15,7 \%$ guru mendapatkan gaji antara Rp 3.276.901,00 - Rp 3.988.200,00 yang tergolong sedang.

Selanjutnya sebanyak $62,8 \%$ guru mendapatkan TPP yang tergolong tinggi yaitu antara Rp 3.415.167,00 - Rp 3.947.800,00 setiap bulan. Sebanyak 33,3\% guru mendapatkan TPP antara Rp 2.349.900,00 - Rp 2.882.533,00 yang tergolong rendah. Sedangkan sisanya sebanyak 3,9\% responden mendapatkan TPP per bulan antara Rp 2.882.534,00 - Rp 3.415.166,00 yang tergolong sedang.

Berdasarkan penghasilan tambahan rata-rata per bulan, sebanyak $60,8 \%$ guru mendapatkan tidak lebih dari Rp 500.000. Sebanyak 19,6\% guru menerima penghasilan tambahan rata-rata per bulan lebih dari Rp 2.000.000,00. Sebanyak 11,8\% guru mendapatkan antara Rp 1.000.001,00 - Rp 1.500.000,00 dan 5,9\% guru menerima penghasilan tambahan rata-rata per bulan antara $\mathrm{Rp} \mathrm{1.500.001,00} \mathrm{-} \mathrm{Rp} \mathrm{2.000.000,00.} \mathrm{Sedangkan} \mathrm{hanya}$ $2 \%$ guru yang menerima penghasilan tambahan rata-rata per bulan antara Rp 500.001,00 - Rp 1.000.000,00

Menurut jumlah pengeluaran rata-rata per bulan untuk mendukung pekerjaan, sebanyak 27,5\% guru membelanjakan penghasilannya antara Rp 250.001,00 - Rp 500.000,00 per bulan untuk mendukung pekerjaan. Sebanyak 21,6\% guru menggunakan Rp $250.000,00$ per bulan untuk mendukung pekerjaannya. Selanjutnya masing-masing $19,6 \%$ guru mengeluarkan sejumlah uang rata-rata antara $\mathrm{Rp} 500.001,00$ - Rp 750.000,00 per bulan dan lebih dari Rp 1.000.000,00 per bulan untuk mendukung pekerjaannya. Sedangkan sebanyak 11,8\% guru mengeluarkan sejumlah uang rata-rata antara Rp 750.001,00 - Rp 1.000.000,00 per bulan untuk mendukung pekerjaannya.

\section{Kompetensi profesional guru}

Berdasarkan jawaban responden, kondisi kompetensi profesional guru di SMA Negeri 13 Surabaya secara keseluruhan tergolong dalam kategori baik. Skor rata-rata atas indikator kompetensi profesional guru yang tertinggi adalah menguasai materi, struktur, konsep, dan pola pikir keilmuan yang mendukung mata pelajaran yang diampu dan menguasai standar kompetensi dan kompetensi dasar mata pelajaran yang diampu. Sedangkan yang terendah adalah memanfaatkan teknologi informasi dan komunikasi untuk mengembangkan diri. Secara lengkap perolehan skor rata-rata indikator kompetensi profesional guru sebagai berikut: menguasai materi (dalam kategori sangat baik) seban- 
yak 21,02\%, menguasai SK dan KD mapel yang diampu (dalam kategori sangat baik) sebanyak 21,02\%, mengembangkan materi secara kreatif (dalam kategori sangat baik) sebanyak 17,91\%, mengembangkan keprofesionalan berkelanjutan (dalam kategori baik) sebanyak 20,23\%, dan memanfaatkan teknologi informasi dan komunikasi (dalam kategori baik) sebanyak $19,83 \%$.

Persamaan regresi yang diperoleh berdasarkan hasil penelitian dituliskan dalam bentuk persamaan regresi sebagai berikut: $\mathrm{Y}=1,345+0,431 \mathrm{X} 1+0,271 \mathrm{X} 2+$ ei. Dari persamaan tersebut diketahui bahwa kedua variabel bebas memiliki koefisien regresi dengan arah positif. Hal ini berarti ada hubungan searah antara variabel bebas terhadap variabel terikat. Dengan demikian semakin tinggi budaya organisasi dan status sosial ekonomi akan meningkatkan kompetensi profesional guru.

Hasil uji F menunjukkan nilai Fhitung sebesar 28,528 dengan signifikansi 0,000 lebih kecil dari 5\%. Hal ini berarti bahwa budaya organisasi dan status sosial ekonomi secara simultan berpengaruh terhadap kompetensi profesional guru.

Koefisien determinasi (R-square) yang dihasilkan dalam penelitian ini sebesar 0,543 menunjukkan bahwa budaya organisasi (X1) dan status sosial ekonomi (X2) berpengaruh terhadap kompetensi profesional guru (Y) sebesar 54,3\% sedangkan sisanya 45,7\% dipengaruhi oleh faktor lain yang tidak dibahas pada penelitian ini.

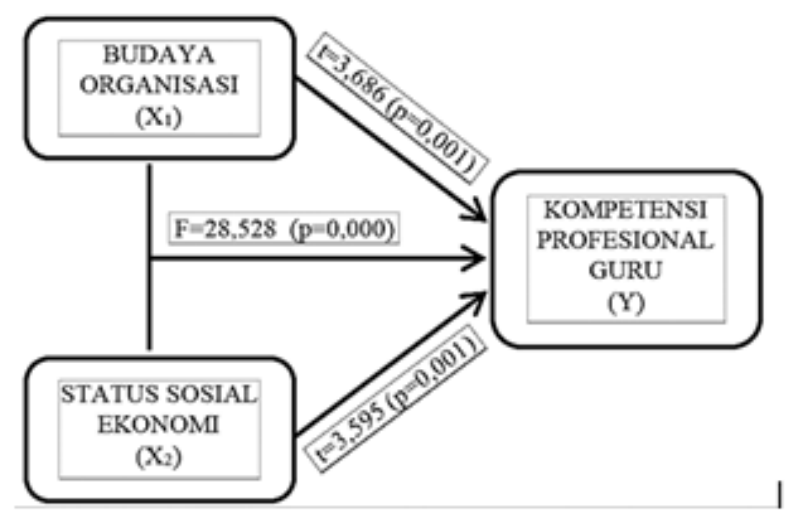

Gambar 1. Hasil uji hipotesis

Lebih lanjut uji parsial menunjukkan bahwa semua variabel mempunyai pengaruh yang signifikan. Uji parsial menunjukkan nilai thitung pada variabel budaya organisasi (X1) sebesar 3,686 dengan tingkat signifikan sebesar 0,001, thitung pada variabel status sosial ekonomi (X2) sebesar 3,595 dengan tingkat signifikan sebesar 0,001. Dengan tingkat signifikasi yang kurang dari 5\% menunjukkan bahwa budaya organisasi dan status sosial ekonomi secara parsial berpengaruh signifikan terhadap kompetensi profesional guru (Y).

\section{Pembahasan}

\section{Pengaruh Budaya Organisasi Terhadap Kompetensi Profesional Guru}

Berdasarkan hasil penelitian mengenai pengaruh budaya organisasi terhadap kompetensi profesional guru menunjukkan bahwa budaya organisasi secara parsial berpengaruh positif dan signifikan terhadap kompetensi profesional guru. Hipotesis kerja yang menyatakan "Diduga ada pengaruh signifikan budaya organisasi terhadap kompetensi 
profesional guru di SMA Negeri 13 Surabaya" teruji kebenarannya. Hal ini ditunjukkan dari nilai thitung pada variabel budaya organisasi (X1) sebesar 3,686 dengan tingkat signifikan sebesar 0,001 lebih kecil dari 5\%, artinya semakin tinggi budaya organisasi semakin tinggi pula kompetensi profesional guru.

Lebih lanjut berdasarkan koefisien regresi pada variabel budaya organisasi sebesar 0,431 , nilai positif pada variabel ini menunjukkan bahwa budaya organisasi memiliki pola hubungan yang searah dengan kompetensi profesional guru yaitu semakin kuat budaya organisasi maka semakin baik kompetensi profesional guru. Jika budaya organisasi semakin rendah maka akan semakin buruk kompetensi profesional guru. Hasil temuan tersebut sesuai teori dalam McShane (2008: 466) menyebutkan bahwa "a strong corporate culture potentially increases a company's success."

Hasil penelitian ini sesuai penelitian Dalminah (2013) yang menyimpulkan bahwa ada pengaruh antara budaya organisasi terhadap profesionalisme guru. Hasil penelitian ini juga sesuai dengan hasil penelitian yang telah dilakukan oleh Sugeng (2012) yang menyatakan bahwa "budaya organisasi sekolah yang baik akan menimbulkan iklim sekolah yang nyaman yang akan mampu meningkatkan kinerja semua komponen sekolah. Guru akan dapat mengembangkan kemampuan profesionalnya baik untuk siswa (sekolah) maupun untuk dirinya sendiri". Penelitian ini juga sesuai hasil penelitian yang telah dilakukan oleh Ojo (2010) yang menyatakan bahwa "there is a positive relationship between organisational culture and corporate performance." Selanjutnya Ojo menambahkan bahwa "we can infer that organisational culture plays vital roles in corporate performance." Hasil penelitian ini juga sesuai dengan penelitian yang telah dilakukan oleh Brahmasari dan Suprayetno (2008) yang menyimpulkan bahwa budaya organisasi berpengaruh positif dan signifikan terhadap kinerja perusahaan. Hasil penelitian ini juga sesuai dengan penelitian yang telah dilakukan oleh Koesmono (2005) yang menyimpulkan bahwa budaya organisasi berpengaruh terhadap motivasi dan kepuasan kerja serta kinerja. Demikian juga atas penelitian yang telah dilakukan oleh Lim (1995) yang menyimpulkan bahwa "a strong organizational (pen.) culture as a positive influence on organizational performance".

\section{Pengaruh Status Sosial Ekonomi Terhadap Kompetensi Profesional Guru}

Berdasarkan hasil penelitian mengenai pengaruh status sosial ekonomi terhadap kompetensi profesional guru menunjukkan bahwa status sosial ekonomi berpengaruh positif dan signifikan terhadap kompetensi profesional guru. Hipotesis kerja yang menyatakan "Diduga ada pengaruh status sosial ekonomi terhadap kompetensi profesional guru di SMA Negeri 13 Surabaya" teruji kebenarannya. Hal ini ditunjukkan dari nilai thitung pada variabel status sosial ekonomi (X2) sebesar 3,595 dengan tingkat signifikan sebesar 0,001 lebih kecil dari 5\%, artinya semakin tinggi status sosial ekonomi semakin tinggi kompetensi profesional guru.

Koefisien regresi pada variabel status sosial ekonomi sebesar 0,271, nilai positif menunjukkan bahwa status sosial ekonomi memiliki pola hubungan yang searah dengan kompetensi profesional guru yaitu semakin tinggi status sosial ekonomi maka semakin baik kompetensi profesional guru. Namun, jika status sosial ekonomi semakin rendah maka semakin buruk kompetensi profesional guru.

Hasil penelitian ini sesuai dengan teori yang disampaikan Schiffman (2008: 336) bahwa "pada umumnya, semakin tinggi pendidikan seseorang, semakin besar kemungkinan orang itu bergaji tinggi (atau berpenghasilan lebih tinggi) dan mempunyai kedudukan 
yang dikagumi atau dihormati". Semakin baik latar belakang pendidikan seseorang akan semakin baik penghasilan dan status sosialnya. Guru dengan penghasilan dan status sosialnya baik mencerminkan status sosial ekonominya dalam kondisi baik pula.

Status sosial ekonomi menjadi sebuah harapan yang menjadikan guru berupaya untuk selalu meningkatkan kinerja dan kompetensi profesionalnya. Status sosial ekonomi menjadi penumbuh motivasi bagi guru untuk lebih bersemangat dalam melaksanakan profesinya. Sesuai dengan yang disampaikan oleh Victor Vroom (dalam Karsono, 2005) tentang teori harapan (expectancy theory) yang berargumen bahwa "kuatnya kecenderungan untuk bertindak dalam suatu cara tertentu tergantung pada kekuatan suatu pengharapan bahwa tindakan itu akan diikuti oleh suatu keluaran tertentu dan pada daya tarik dari keluaran tersebut bagi individu itu."

Hasil penelitian ini sesuai penelitian Qosim (2012) yang menyimpulkan bahwa ada pengaruh signifikan status sosial ekonomi terhadap perilaku profesional guru. Hasil penelitian ini juga sesuai dengan hasil penelitian yang telah dilakukan oleh Werang (2010) yang menyimpulkan bahwa semakin tinggi tingkat kehidupan sosial ekonomi guru akan berpengaruh kepada semakin meningkatnya kinerja guru. Hasil penelitian ini juga sesuai dengan penelitian yang telah dilakukan Nadeem, dkk (2011) yang menyimpulkan bahwa gaji guru yang rendah menyebabkan terganggunya mental. Selanjutnya Nadeem, dkk menyampaikan bahwa status sosial ekonomi guru berpengaruh pada kinerjanya. Penelitian ini juga sesuai dengan hasil penelitian Nasution dan Arthana (2010) yang menyimpulkan bahwa sertifikasi guru berpengaruh terhadap kompetensi mengajar guru Sekolah Dasar Negeri di Kecamatan Benjeng Kabupaten Gresik.

\section{Pengaruh Budaya Organisasi dan Status Sosial Ekonomi Terhadap Kompetensi Profe- sional Guru}

Berdasarkan hasil penelitian secara parsial budaya organisasi dan status sosial ekonomi berpengaruh signifikan terhadap kompetensi profesional guru. Begitu juga secara simultan, budaya organisasi dan status sosial ekonomi berpengaruh signifikan terhadap kompetensi profesional guru. Hal ini dapat dilihat nilai $\mathrm{F}_{\text {hitung }}$ sebesar 28,528 dengan tingkat signifikan sebesar 0,000 lebih kecil dari 5\%. Berarti budaya organisasi (X1) dan status sosial ekonomi (X2) secara simultan berpengaruh signifikan terhadap kompetensi profesional guru (Y).

Berdasarkan teori McShane (2008: 466) yang menyatakan bahwa budaya perusahaan yang kuat berpotensi meningkatkan kesuksesan perusahaan. Dalam hal ini perusahaan merupakan lembaga/tempat dimana organisasi yang terbentuk di dalamnya dan menjalankan aktifitas pencapaian tujuan perusahaan. Budaya perusahaan juga merupakan budaya organisasi yang ada di dalamya.

Kesuksesan sekolah juga merupakan kesuksesan organisasi dalam mencapai tujuantujuan yang telah ditetapkan. Budaya organisasi sekolah yang kuat menjadikan setiap orang dalam organisasi berkomitmen untuk mencapai tujuan organisasi. Budaya organisasi yang tinggi memacu guru untuk melaksanakan tugas dan kewajiban secara tuntas dengan memilih cara-cara inovatif dan dapat dipertanggungjawabkan.

Status sosial ekonomi menggambarkan posisi seorang guru diantara yang lainnya. Hal ini menjadikan guru memiliki kedudukan yang sesuai dengan lingkungan kelompoknya berdasarkan pengakuan sosial dan kemampuan memenuhi kebutuhannya. Sebagaimana teori yang disampaikan oleh Schiffman (2008: 330) bahwa "Klasifikasi para 
anggota masyarakat ke dalam sejumlah kecil kelas sosial juga telah memungkinkan para peneliti memperhatikan adanya pola nilai-nilai, sikap, dan perilaku bersama diantara para anggota dalam setiap kelas sosial dan nilai-nilai sikap, dan perilaku yang berbeda diantara kelas-kelas sosial".

Menurut teori harapan dari Victor Vroom (dalam Karsono, 2005) yang menyatakan bahwa "kuatnya kecenderungan untuk bertindak dalam suatu cara tertentu tergantung pada kekuatan suatu pengharapan bahwa tindakan itu akan diikuti oleh suatu keluaran tertentu dan pada daya tarik dari keluaran tersebut bagi individu itu". Setiap guru SMA Negeri 13 Surabaya yang mendapatkan sertifikat pendidik telah menikmati peningkatan kesejahteraan dalam bentuk tunjangan profesi pendidik selain dari gaji sebagai guru PNS. Demi tetap medapatkan tunjangan tersebut, guru secara terus menerus berupaya meningkatkan kinerja yang diwujudkan dalam peningkatan kompetensi profesionalnya sesuai standar kompetensi profesional guru yang tercantum dalam Permendiknas Nomor 16 Tahun 2007, tentang standar kualifikasi akademik dan kompetensi guru. Namun perlu dipahami bahwa peningkatan kompetensi guru merupakan tujuan utama, sedangkan tambahan penghasilan dari tunjangan profesi pendidik tersebut adalah konsekuensi logis yang menyertai adanya kompetensi guru yang telah dikuasai.

Guru yang memiliki budaya organisasi yang kuat dengan status sosial ekonomi yang baik akan memiliki kondisi kompetensi profesional guru yang baik pula. Guru dengan komitmen berinisiatif, bebas berpendapat, bertanggung jawab, agresif, inovatif, dan bertoleransi terhadap tindakan beresiko dengan didukung status sosial ekonomi yang baik akan memiliki ketenangan diri dalam melaksanakan tugasnya. Guru tidak akan dipusingkan lagi dengan hal-hal yang berkaitan dengan masalah ekonomi dalam keluarganya. Sehingga guru memiliki komitmen dalam meningkatkan kompetensi profesionalnya menjadi lebih baik.

\section{KESIMPULAN}

Berdasarkan hasil penelitian dan pembahasan, maka dapat disimpulkan bahwa:

1. Pengaruh budaya organisasi signifikan terhadap kompetensi profesional guru di SMA Negeri 13 Surabaya. Hal ini berarti semakin tinggi budaya organisasi pada diri setiap guru, maka akan semakin baik kondisi kompetensi profesional guru-gurunya. Namun, apabila semakin rendah budaya organisasi pada diri setiap guru, maka akan semakin buruk pula kondisi kompetensi profesional guru-gurunya.

2. Pengaruh status sosial ekonomi signifikan terhadap kompetensi profesional guru di SMA Negeri 13 Surabaya. Hal ini berarti semakin baik kondisi status sosial ekonomi pada diri setiap guru, maka akan semakin baik kondisi kompetensi profesional gurugurunya. Namun, apabila semakin buruk status sosial ekonomi pada diri setiap guru, maka akan semakin buruk pula kondisi kompetensi profesional guru-gurunya.

3. Pengaruh budaya organisasi dan status sosial ekonomi secara bersama-sama signifikan terhadap kompetensi profesional guru di SMA Negeri 13 Surabaya. Hal ini berarti semakin baik budaya organisasi dan status sosial ekonomi pada diri setiap guru, maka akan semakin baik kondisi kompetensi profesional guru-gurunya. Namun, apabila semakin buruk budaya organisasi dan status sosial ekonomi pada diri setiap guru, maka akan semakin buruk pula kondisi kompetensi profesional guru-gurunya. 
Peneliti merekomendasikan beberapa saran sebagai berikut:

1. Supaya kompetensi profesional guru semakin tinggi, guru SMA Negeri 13 Surabaya sebaiknya memperkuat budaya organisasi terutama peningkatan kesempatan berinisiatif bagi guru. Semakin tinggi kesempatan berinisiatif mendorong kreatifitas guru dalam mengembangkan kualitas pembelajaran di kelas sesuai dengan bidangnya.

2. Peningkatan status sosial ekonomi perlu memperhatikan linieritas sesuai dengan bidangnya. Linieritas bermakna mengajar sesuai dengan bidangnya dan memberikan kesempatan kepada guru untuk meningkatkan kualifikasi pendidikan lebih lanjut.

3. Perlu dilakukan penelitian lebih lanjut dengan berfokus pada kompetensi profesional guru ekonomi dengan spektrum yang lebih luas.

\section{DAFTAR RUJUKAN}

Brahmasari, Ida Ayu, dan Suprayetno, Agus. 2008. Pengaruh Motivasi Kerja, Kepemimpinan dan Budaya Organisasi terhadap Kepuasan Kerja Karyawan serta Dampaknya pada Kinerja Perusahaan. Jurnal Manajemen dan Kewirausahaan. Vol. 10, No. 2, September 2008, pp: 124-135.

Dalminah. 2013. Pengaruh Budaya Organisasi, Motivasi, dan Kompetensi terhadap Profesionalisme Guru SMP Negeri 17 Semarang. Jurnal Q-MAN. Vol. 2, No. 3, pp: 81-96. Diunduh dari: http://www.journal.usm.ac.id/jurnal/qman/546/ detail/USM_d87f3.pdf (pada hari Kamis, 20 Juni 2013 pukul 11: 02 WIB).

Dewi, Retno Mustika. 2010. Pengaruh Budaya Akademik dan Status Sosial Ekonomi terhadap Kinerja Profesional Guru Ekonomi SMA Se-Kota Malang. Tesis Magister Pendidikan Ekonomi. Universitas Negeri Malang.

Karsono. 2005. Pengaruh Kompensasi terhadap Kinerja Guru SMK Teknologi dan Industri. Jurnal PTM. Volume 5, No. 1. Juni 2005. pp: 19-24.

Koesmono, H. Teman. 2005. Pengaruh Budaya Organisasi terhadap Motivasi dan Kepuasan Kerja serta Kinerja Karyawan pada Sub Sektor Industri Pengolahan Kayu Skala Menengah di Jawa Timur. Jurnal Manajemen dan Kewirausahaan Vol. 7, No. 2. September 2005. pp: 171-188.

Kunandar. 2007. Guru Profesional - Implementasi kurikulum Tingkat Satuan Pendidikan (KTSP) dan Sukses dalam Sertifikasi Guru. Jakarta: Rajawali Pers.

Lim, Bernard. 1995. Examining the Organizational Culture and Organizational Performance Link-A critical review of the methodologies and findings of recent researchers into the persumed link between culture and performance. Leadership \& Organization Development Journal. Vol. 16. No. 5. pp: $16-21$.

McShane, Steven L., \& Von Glinow, Mary Ann. 2008. Organizational Behavior - 4th edition. New York: McGraw-Hill/Irwin.

Nadeem, Mohammad., Shaheen Rana, Musarrat., Hameed Lone, Abdul., Maqbool, Saira., Naz, Khanza., \& Ali, Akhtar. 2011. Teacher's Competencies and Factors Affecting the 
Performance of Female Teachers in Bahawalpur (Southern Punjab) Pakistan. International Journal of Business and Social Science. Vol. 2. No. 19. Oktober 2011. pp: 217 -222 .

Nasutiyon, Wisnu B. dan Arthana, I Ketut Pegig. 2010. Pengaruh Sertifikasi Guru terhadap Kompetensi Mengajar Guru Sekolah Dasar Negeri di Kecamatan Benjeng Kabupaten Gresik. Jurnal Teknologi Pendidikan. Vol. 10. No. 2. Oktober 2010. pp: $47-62$.

Ojo, Olu. 2010. Organisational Culture and Corporate Performance: Empirical Evidence from Nigeria. Journal of Business Systems, Governance and Ethics. Vol. 5. No. 2. pp: $1-12$.

Qosim, Nur. 2012. Pengaruh Kompetensi Guru, Status Sosial Ekonomi, Sikap dan Minat terhadap Perilaku Profesional Guru di SMA/MA Se-Kabupaten Demak. Journal of Economic Education. Vol. 1. No. 1. pp: $32-38$.

Robbins, P. Stephen. 2007. Teori Organisasi: Struktur, Desain dan Aplikasi, Edisi Kesepuluh. Terjemahan. Jakarta: Indeks.

Robbins, P. Stephen. 2002. Prinsip-prinsip Perilaku Organisasi, Edisi Kelima. Alih Bahasa Halida dan Dewi Sartika. Jakarta: Erlangga.

Sarimaya, Farida. 2008. Sertifikasi Guru - Apa, Mengapa, dan Bagaimana?. Bandung: CV. Yrama Widya.

Schiffman, Leon G., \& Kanuk, Leslie Lazar. 2008. Perilaku Konsumen - Edisi ketujuh. Jakarta: PT. Indeks.

Solomon, Michael et al. 2006. Consumer Behaviour: An European Perspective. 3rd Edition. England: Pearson Education Limited.

Sugeng. 2012. Pengaruh Kompetensi Manajerial Kepala Sekolah dan Budaya organisasi terhadap Kinerja Guru SMP Negeri di Kabupaten Kudus. Jurnal Educational Management. Vol. 1 No. 1. pp: 63-70.

Sugiyono. 2001. Statistika untuk Penelitian. Bandung: Alfabeta.

Werang, Basilius Redan. 2010. Pengaruh Keterampilan Manajerial Kepala Sekolah dan Status Sosial Ekonomi Guru terhadap Kinerja Guru SMA Negeri 1 Merauke-Papua. Jurnal Aplikasi Manajemen. Volume 8 Nomor 2 Mei 2010. pp. 421-429.

2005. Undang-Undang Republik Indonesia Nomor 14 Tahun 2005. Tentang Guru dan Dosen. Diunduh dari: http: //advokat-rgsmitra.com/ (pada hari Senin, 18 Pebruari 2013 pukul 17: 20 WIB).

2007. Peraturan Menteri Pendidikan Nasional Republik Indonesia Nomor 16 Tahun 2007. Tentang Standar Kualifikasi Pendidik dan Kompetensi Guru. Diunduh dari: http: //www.google.com/ (pada hari Kamis, 28 Pebruari 2013 pukul 03: 15 WIB). 